\title{
Indigenous higher education in Mexico and Brazil: between redistribution and recognition
}

Juan de Dios Oyarzún, Cristina Perales Franco and Tristan McCowan

(UCL Institute of Education, University College London)

Published in 2017 in Compare, 47 (6), 852-871.

\begin{abstract}
Indigenous groups in Latin America face a double exclusion from higher education, with low levels of access to institutions, and little acknowledgement of their distinctive cultural and epistemological traditions within the curriculum. This article assesses current policies in Mexico and Brazil towards indigenous populations in higher education, considering the various responses to the challenge, including affirmative action programmes in mainstream universities, intercultural courses and autonomous institutions. These policies and initiatives are analysed using the theoretical frames of redistribution and recognition, focusing on demands for formal equality and material well-being on the one hand, and a distinctive cultural and educational space on the other. While state-sponsored policies focus primarily on the redistributive element, initiatives based on recognition come largely from autonomous organisations, raising a series of dilemmas and tensions around educational justice for indigenous populations in the region.
\end{abstract}

Keywords: affirmative action; Brazil; higher education policy; indigenous education; Mexico

\section{Introduction}

The question of whether marginalized groups in society should have access to mainstream or differentiated provision is a long-standing - perhaps a perennial - concern of educational policy and practice. On the one hand, it is argued that the curriculum in the mainstream school system is culturally specific, and reflects the knowledge traditions and interests of dominant groups in society: simply inserting non-dominant groups into this context would, therefore, serve to undermine their distinctive traditions and likely lead to their failure according to conventional criteria. Theorists such as Boaventura de Sousa Santos (2015) have instead proposed an approach based on 'ecology of knowledges', or in Andreotti's (2011) terms 'learning to read the world through other eyes', to acknowledge these diverse and equally valid forms of knowing. On the other hand, there are those (e.g. Clegg 2011; Young 2008; Wheelahan 2007) who argue that justice requires that marginalised populations have access to the mainstream curriculum, characterised as 'powerful' or 'context independent' knowledge. According to this latter thesis, differentiated curricula simply lock peripheral social groups into a cycle of disadvantage, as they are then unable to access valued opportunities in society without mainstream scientific knowledge and conventional qualifications. 
This article aims to explore this tension in the context of indigenous groups in the region of Latin America. Indigenous groups around the world are strongly bound up in the complex debate about equality and difference (Aikman 1997). Defined alternately as original populations marginalized in the context of colonization and settlement, or a national minority with a significantly distinct culture at risk from a majority population, they face a range of challenges in the education system. Having a distinct culture and particular knowledge traditions, and in many cases a different language, there are threats posed to the integrity and continuity of those traditions if young people are attending formal educational institutions. Yet many communities see the need for formal educational experiences and qualifications in order to strengthen their ability to negotiate their survival and prosperity within mainstream society (May 1999; Spring 2000).

Latin America is a region in which issues of indigeneity are particularly prominent. Spanish and Portuguese colonization from the $16^{\text {th }}$ century onwards had a catastrophic impact on the existing inhabitants of the region, with widespread loss of life through slaughter and illness, and a progressive loss of culture and identity through deliberate suppression of cultural forms by the Church and state, and through the more subtle, but no less pernicious, influence of mainstream media, art, fashion and patterns of consumption. In a few countries, there are still large indigenous communities, particularly the Quechua and Aymara in the Andes, the Guarani in Paraguay and adjacent countries, and the Maya in Mesoamerica. In the cases of Bolivia, Peru and Guatemala indigenous groups are close to being a majority of the population. However, the question of indigeneity has been made significantly more complex by the extensive miscegenation in the region over the last five centuries, leading to significant mestizo (mixed race) populations, and the emergence of mestizo culture and national identity. Indigeneity does not always equate to ancestry, with large proportions of those with indigenous heritage not self-identifying as indigenous, particularly if they are first language Spanish or Portuguese speakers.

As elsewhere in the world, indigenous people in Latin America are significantly disadvantaged in the area of education. While across this large region there are inevitable differences between national contexts and specific indigenous groups, in all contexts indigenous people have lower rates of access to formal education, and where it is possible to gauge, worse learning outcomes (see Cueto et al. 2009 and 2011 for the case of Peru). Yet it is not only an issue of neglect, there is also contestation (within as well as outside indigenous communities) over which forms of education are most appropriate. The most common dimension has been that of language, with debates stretching back decades over the use of indigenous languages in schools, either exclusively or as part of bilingual education programmes (Ames 2012, Hornberger 1988; Skutnabb-Kangas et al. 2009). There have also been more radical calls for the decolonization of the curriculum (most prominently in Bolivia in the administration of Evo Morales), and the inclusion of indigenous history and knowledge traditions (Howard 2009; Lopes Cardozo 2012). In some cases separate indigenous schools have emerged, yet these initiatives are still far from attending either to the quantitative gap in terms of access to formal education, or the problems associated with quality.

This article focuses on initiatives relating to indigenous groups at the level of higher education. This level demonstrates both the severe constraints on access for these groups, 
and even greater barriers in terms of differentiation of the curriculum than those at school level. It aims to assess the responses that have been made by governments (often reacting to the pressures placed on them by social movements) to address these injustices, and to understand how these responses have been located in relation to the above-mentioned tensions around inclusion. As outlined in greater detail below, the article conceptualizes the debate in relation to the binary of redistribution and recognition, as debated in the work of Fraser, Honneth and others. To a large extent, the redistribution position corresponds to the emphasis on access to powerful knowledge outlined above, and recognition to differentiated provision and multiple knowledges. This frame is used to categorize and also to problematize higher education policies and initiatives relating to indigenous people in Latin America. It is acknowledged that - like all binaries - this one is somewhat reductive, and real-life phenomena cannot be easily placed into one or other of the boxes. The limitations of using a frame emerging from Western philosophy and politics for analysing indigenous issues is also fully acknowledged. Nevertheless, the theoretical frame is considered to be generative in terms of opening up our understanding of the possibilities and trade-offs of different forms of educational intervention for social justice.

Given the challenges in characterizing the whole of such an extensive and diverse region, the article will focus on two specific countries, Mexico and Brazil. These have been chosen, first, because they are the two largest countries in Latin America in terms of population, and in consequence exert a significant economic, political and cultural influence on the region; and second, because they illustrate well the challenges and contradictions of indigenous higher education. As will be explored further below, both Brazil and Mexico have to a large extent adopted an approach of equal rights to accessing mainstream institutions, while allowing for some differentiation of provision, in particular Mexico with the innovative 'intercultural universities'. In focusing on these two countries, it is recognized that they do not in any way 'stand for' the experience of the entire region, while at the same time demonstrating some trends that can be identified across many countries. The article is primarily theoretical and exploratory, and does not present newly collected empirical data: it utilizes secondary literature as well as primary documentation in some cases in order to draw out the implications of each of the contexts, and the diverse experiences within each. The analysis is also informed by the authors' experience of participation in educational initiatives and research projects in the two countries in question, and elsewhere in Latin America, over many years.

There will first be an outline of the theoretical discussions around redistribution and recognition, before applying these ideas to the two cases of Mexico and Brazil. Finally, implications of these cases are drawn out for our understandings of indigenous higher education around the world.

\section{Justice as redistribution or recognition?}

This section will address in turn the notions of equality and difference, their two corollaries, redistribution and recognition, and the processes entailed in addressing injustice associated with each. 
a. Equality and redistribution.

The equality principle is related to the politics of redistribution, a philosophical perspective which states that the main problem of social injustice is inequality, so its political objective or solution is focused on redistributing among the disadvantaged. The argument is based primarily on economic inequality and economic redistribution, and the corresponding policies are commonly illustrated in liberal States through economic redistribution from tax collection, with higher taxes from wealthier individuals or companies, redistributed among disadvantaged populations. That logic is materialized in particular redistributive policies, such as subsidy policies which, for instance, are found in certain housing policies that give economic support to disadvantaged families in order to acquire their own house. But redistributive policies can also adopt strategies to reinforce equality principles or objectives, without being based on money or material transfers. An example can be found in affirmative action policies in education, in which for instance students from disadvantaged backgrounds receive special support in order to equalize their situation with the rest of the students. In this last case, even if the support is academic, the motive and purpose of the policy is economic, from the assumption that socioeconomic disadvantage has led to academic difficulties.

The origins of this theoretical perspective come mainly from the liberal tradition, and the theory of justice presented by its foremost exponent in the 20th century, John Rawls. Beyond that, Nancy Fraser (1995) also locates the origins of the redistribution paradigm in the socialist imaginary of equality and redistribution under the premises of class interests and class exploitation. Given that the social problem of inequality is seen to be "rooted in the economic structure of society" (Fraser \& Honneth, 2003, p. 13), this vision of society is structured by a notion of social class:

To say that a society has a class structure is to say that it institutionalizes economic mechanisms that systematically deny some of its members the means and opportunities they need in order to participate on a par with others in social life (Fraser \& Honneth, 2003, pp. 48-49).

In terms of social oppression, the equality/redistributive perspective sees that certain social groups are oppressed by class structures which deprive them of equal access to different fields of society, in contrast to the politics of recognition, which understands oppression in terms of hegemonic cultural discourses which make invisible certain cultural identities. Even though Fraser acknowledges issues around culture and identity in problems of inequality - as Honneth does with economic ones in his politics of recognition - the emphasis lies on economic factors, where injustice and inequality are rooted, and from there can be found the principal policies to respond to these problems: policies of redistribution. As may be inferred, this theoretical standpoint is criticized for being excessively based in materialist arguments, leaving aside cultural issues that nowadays seem to be increasing in importance regarding the understandings of social injustice. 


\section{b. The politics of recognition.}

The second perspective to consider is the recognition approach originally proposed by the philosophers Charles Taylor (1994), and later by Axel Honneth $(1992,2004)$, among others, an approach that problematizes the notion of recognition in modern multicultural societies. In short, the authors analyze the concept of recognition as the basis of the development of individual and collective identity. In a multicultural world, the idea of equality is not sufficient to safeguard human dignity, the subsequent step then is to recognize the other, not only in their fundamental rights shared by everyone - from which it is possible to establish the notion of equality - but in their particularities, identities and even precarities. An example can be found in tensions with indigenous people and their quest for political and constitutional recognition in which the idea of equality is not enough, as the problem lies precisely in the lack of understanding of their ethnic-cultural particularity.

From this recognition standpoint, the centrality lies in matters of culture rather than political economy, as "cultural domination supplants exploitation as the fundamental injustice" (Fraser, 1998), and in the struggles distinctive of the post-socialist society and its political frame, "group identity supplants class interests as the chief medium of political mobilization" (Fraser, 1998). Being a matter of culture, the politics of recognition look for "cultural and symbolic change" (Fraser \& Honneth, 2003, p. 13), rather than an economic solution, as a response to the problem of social injustice. This symbolic feature is understood as "patterns of representation, interpretation and communication" (Fraser \& Honneth, 2003, p. 13), patterns which hegemonize certain discourses over others, and within them, certain social codes of validation over others, because to assert that:

(...) a society has a status hierarchy is to say that it institutionalizes patterns of cultural value that pervasively deny some members the recognition they need in order to be full, participating partners in social interaction. (Fraser \& Honneth, 2003, p. 49)

So, the recognition paradigm can also be referred to as the politics of identity or difference, because its postulates are based in the need of reaffirm differences, instead of erasing them. The collective and common nature of recognition is linked to community, which has led Taylor to identify political communitarianism as one of its main philosophical backgrounds (Friedman, 1994) -But also nowadays politics of recognition are applied by the analysis of emerging social movements - indigenous, feminist, gay, among others - which make explicit the need for social, and even legal or constitutional recognition in order to respond to their claims.

It is this 'new' type of post-socialist injustice which explains the claim for recognition, with social movements which replace the workers' movement as the contemporary voices denouncing the new forms of injustice plotted in practices of misrecognition (Touraine, 2002). The fundamental conceptual ingredient in this alternative is the political recognition of the uniqueness and authenticity of each individual or collective subjectivity in the context of a pluralist society.

A final contribution must be mentioned in relation to the theoretical perspectives outlined: namely, the critique from indigenous decolonialist theorists towards Western 
political frameworks in their pretension of encompassing demands and conflicts from indigenous populations (Coulthard, 2014) and inability to reach the profundity and complexity of such historical struggles (Watson, 2005). These critiques assert that the Western eye cannot perceive the worldview of indigenous thinking - and thus the real nature of their historical demands and subsequent possible political solutions. Intercultural and inclusive policies in education, therefore, fail in integrating the indigenous 'episteme' into the educational field (Kuokannen, 2007), as these efforts tend to include indigenous culture as 'the other' in an unequal position in relation to Western culture. These critical standpoints will be addressed in the discussion section, and will complement the theories presented.

Having the above discussion as framework of analysis it now follows an outline of the current status and key trends in higher education relating to indigenous populations in Mexico and Brazil, leading to an application of these notions of redistribution and recognition.

\section{Higher education and the indigenous population in Mexico}

It is estimated that $10 \%$ of the total population of Mexico of 119 million are indigenous understood as people in a household where at least one person speaks an indigenous language. The percentage increases to $21.5 \%$ when people are counted by selfadscription to an indigenous group (CDI, 2016) ${ }^{1}$. There are 68 linguistic groups and 364 language variations (DOF, 2008). The indigenous population is spread across the territory, but is especially concentrated in the southern states where some municipalities have up to $100 \%$ of indigenous households (CDI, 2016). International and national studies show that indigenous people have the lowest indicators in terms of social development. Overall, $95 \%$ of them were considered poor or vulnerable, in contrast with the $43.2 \%$ of the rest of the population (UNICEF/INEE, 2016, p. 9). Although the access of indigenous people to basic education is almost universal at the primary level $(97.6 \%)$, in the 15-17 age group only 50\% of the indigenous adolescents attend school, compared to the $74.8 \%$ in the general population. For the 18-24 age group the percentage drops to $20 \%$ for indigenous youth attending some type of education and to $13.6 \%$ for those that only speak an indigenous language (CDI, 2016).

There is no concrete information regarding the quantity of indigenous young people in higher education since most public universities do not register the ethnicity of their students, although it is estimated that only 1\%-3\% of indigenous youth participate at this level (Schmelkes, 2009, p. 6). The lack of ethnic differentiation is a common trend in Mexican society: ethnicity is rarely recorded in everyday and official processes, a fact that can be attributed to the national construction of identity based on the mestizo ideal, the combination of both Spanish and Indigenous heritage (Vasconcelos, 1948 in Mateos Cortés \& Dietz, 2011, p. 63). This national construction plays an important part in the history of indigenous education in Mexico, which aimed first to assimilate indigenous people into the general society and used Spanish as the main vehicle. Later the emphasis was placed on integrating them into the national and regional strategies of development.

\footnotetext{
${ }^{1} 2015$ was the first year in which people were asked if they self-ascribed to an indigenous group. Before this year, the linguistic criterion was the only one used to estimate the size of the indigenous population.
} 
In the 1970s, social demands for a recognition of the pluri-ethnic composition of the country promoted the creation of a bilingual and bicultural education system, but the use of indigenous languages mostly had the objective of providing a better initiation into the dominant culture. In the 1990s, new approaches recognizing the specific characteristics and claims of the indigenous groups were demanded and some modifications were made to normative instruments (e.g. articles in the Constitution and the General Education Law). These combined with general policies of inclusion and improvement of access conditions for targeted minority groups have opened up some options of higher education for indigenous students (Badillo Guzmán, Casillas Alvarado, \& Ortiz Méndez, 2008; SEP, 2004; Tapia Guerrero, 2016). Following the classification made by Bertely Busquets (2011) of the different institutions for indigenous or intercultural higher education, three general options or types of programmes can be identified:

1. Teacher training programmes for indigenous people in and for intercultural contexts.

This option groups together different university level programmes aimed at training indigenous teachers who will ideally work in intercultural settings. Historically these programmes have been the most prominent in Mexico, with a Bachelor's degree in Primary Education for Indigenous Contexts, for example, created in the 1980s (Martínez Casas, 2011). Currently these programmes are offered mostly by the National Pedagogic University that has teaching units across the country. Student teachers can also attend the Normales, the official teacher training universities, and can be certified while in service as well (Bertely, 2011 p. 69). This higher education option is probably the most common for indigenous students, with Carnoy et al. (2002, p. 38) asserting in a 2002 study that most indigenous professionals were employees of the educational system.

2. University level programmes where indigenous students participate.

\section{i. General public and private universities.}

Indigenous students are also enrolled in the general public universities as regular students. It is important to point out that there is not a quota system in Mexico to foster the access of indigenous students to higher education. The universities are usually in the main urban centres, including cities in regions with a high percentage of indigenous population. In 24 general universities indigenous students are supported by the affirmative action programme Pathways to Higher Education. Funded by the Ford Foundation until 2008, and later continued by the Universities and Higher Education Institutions Association (ANUIES) with funding from the universities themselves, the World Bank and Mexican Public Education Secretariat (Alcántara Santuario \& Navarrete Cazales, 2014; ANUIES, 2007; Didou Aupetit \& Remedi, 2006; Didou-Aupetit, 2013; Flores-Crespo \& Barrón Pastor, 2006; Schmelkes, 2013), Pathways provides academic support, mentorship spaces, teacher seminars about interculturality, and aids the students in accessing resources through scholarships, grants and services of food, housing and networking (Gómez, 2011 in Alcántara Santuario \& Navarrete Cazales, 2014, p. 229). The students in this programme, as in the intercultural universities described below, can apply for a scholarship for low-income students called PRONABES (CNBS-SEP, 2016). In the case of the National Autonomous University of Mexico (UNAM), the largest university in Mexico, indigenous students have since 2004 also been able to apply for a scholarship as part of the University Programme of Cultural Diversity and Interculturality (UNAM, 2014). These programmes seem to acknowledge the need for support of 
indigenous students as a disadvantaged minority, placing less emphasis on their cultural and identity demands and characteristics. A study carried out by Schmelkes (2013: 144) found that:

in universities, being indigenous is synonymous with being poor and having poor educational background, (universities) saw their role with respect to Indigenous students as 'helping them out' to surmount these difficulties. Indigenous students are culturally rich, though they might be and generally are economically poor. Universities see their economic poverty, not their cultural wealth.

\section{ii. Intercultural Universities}

There are currently 12 intercultural universities (IU) created by the Mexican Government plus another two autonomously created that have been officially recognized. These universities, which started to operate in 2003, are not exclusive to the indigenous population (Schmelkes, 2009), but, in contrast with the occidental urban-centric and classist university tradition in Mexico, they are located in indigenous regions, in cultural settings characterized by high economic exclusion and infrastructural marginalization (Mateos Cortés \& Dietz, 2016, p. 684). By being situated in such regions the main purposes of these universities are to increase the proportion of indigenous students in higher education, to educate professionals engaged with regional development and to form links with the communities in which they are located (Schmelkes, 2008).

The IU project was generated by the convergence of the goals of social policy (aimed at fighting poverty), higher education policy oriented towards an increase in coverage, the formation of human capital and the intercultural agenda, promoted by the national and international indigenous movement (Tapia Guerrero, 2016). Although there seems to be an inclusion of both redistribution and recognition components in the IU model, there is an inherent tension between state aims of economic development and poverty reduction, and the demands historically made by the indigenous groups. Schmelkes (2009) states that these are mainly three: access to bilingual and culturally pertinent education; better national knowledge and appreciation of indigenous culture and to decide about their own educational systems (with the necessary resources to plan, execute and evaluate them). For this author, IUs "are clearly an answer to the first of these demands. In time, they should become a main instrument for the gradual fulfilment of the other two" (2009 p. 89). Other analyses challenge the possibility of addressing these demands, since IUs have been subordinated to the national public policy and to a particular model of understanding intercultural relations (e.g. Tapia Guerrero, 2016), positioning this system more as a case of affirmative action (Lehmann, 2015). The way the intercultural approach is portrayed in the academic model of the university (Casillas Muñoz \& Santini Villar, 2006) seems to respond to a liberal view of multiculturalism that fails to problematize the systemic differences and power relations.

\section{Autonomous and semi-autonomous options.}

These programmes group "autonomous and semi-autonomous options in political, normative and pedagogical terms, which are generated in highly politicized, militarized and conflictual regions where the indigenous movement has taken roots" (Bertely Busquets, 2011, p. 70). Some of these grassroots initiatives are in permanent negotiation or struggle for official recognition (UNISUR Guerrero and UESA-LEIC for example in Rojas-Cortés \& González-Apodaca, 2016). Others reject the official and Westernized 
system and provide autonomous options, as is the case of UNTIERRA, the University of the Earth, in the state of Oaxaca whose purpose is to "provide a tertiary learning space, supporting and complementing existing non-formal, autonomous community education initiatives" (Khoo \& Walsh, 2016). This 'university' defines its processes by exploring the needs of the communities and the kind of learning they want from their young people (Barrón-Pastor, 2010) and it is tied to the work and demands of indigenous and social movements in the country (UNITIERRA, n.d.). For Rojas-Cortés and González-Apodaca (2016) these initiatives are based on:

the positive claim of their "own" identity and culture, the critique of the hegemonic ways of knowledge and wisdom, the legitimacy of "other" wisdom tied to the cultural and political praxis of the actors, and the defence of territory and collective resources ${ }^{2}$.

The authors argue these educational understandings are not reflected in the governmental agendas for intercultural education, but they seem to be a constitutive element of the autonomous types of higher education institutions.

In Mexico the heterogeneous and contested field of indigenous and intercultural higher education is shaped by the struggle in the relation between meaning and power that runs through it and that intertwines diverse representations of social equity (Rojas-Cortés \& González-Apodaca, 2016). The higher education programmes are diverse and the different characteristics of the systems, regions of the country and ethnic groups make it especially challenging to give a brief summative view. It is clear that indigenous participation in education is marked by a homogenizing past and a long struggle for cultural and ethnic recognition and for social and economic dignity and well-being. It is also clear that in the first two types of programmes actual participation of indigenous people in the configuration of the higher education system has been marginal and therefore recognition demands become instrumental for an approach much more aligned with redistribution. In contrast, the third type of programme is situated in the recognition approach that aims not just to make difference explicit, but to reshape educational, economic and social relationships at the communal, regional and state level.

\section{Challenges of indigenous higher education in Brazil}

Higher education in Brazil - like all aspects of society - is subject to high levels of inequality. Significant expansion of the system in recent years, primarily through relatively low-cost private institutions, has enabled larger numbers of the population to go to university, but there is still significant unmet demand, and disadvantaged students are generally confined to lower quality institutions (Author 2007; Pedrosa et al. 2014). Beyond social class and income inequalities, there are significant racial/ethnic disparities.

The Brazilian population - comprised of the original indigenous population, European settlers, the descendants of African slaves and more recent migrant groups from Asia and other parts of the world - has historically been characterized by high levels of interracial marriage, making it hard to divide society into clear racial/ethnic groups. The Brazilian census, and other statistical analyses, however, do distinguish between white, pardo (mixed race), black, indigenous and East Asian. Of these groups, most of the attention has

\footnotetext{
${ }^{2}$ Quotation originally in Spanish, translated by the authors.
} 
been on the severe disparity in access to higher education between African descendants (often combining black and mixed-race populations) and the white population.

While there are very high numbers of descendants of indigenous peoples in Brazil, most of these have been integrated into mainstream society, speak only Portuguese and do not self-identify as indigenous. There are a total of 230 indigenous communities in the country, speaking 180 different languages (Lima 2012), although the number of people in Brazil declaring themselves as indigenous according to the 2010 census is 817,963, comprising just $0.43 \%$ of the population (IBGE 2012). Given the relatively small numbers, there has been less attention to indigenous peoples than there has for African Brazilians, with the exception of the Amazon region in which a large proportion of indigenous peoples are located. Educational provision for these communities had in the first centuries of European conquest been provided by missionaries, and then in the $20^{\text {th }}$ century through the state in a predominantly assimilationist mode (David, Melo \& Malheiro 2013). However, the 1988 Constitution, formed after the end of the military dictatorship, made important guarantees of alterity for indigenous groups, while the Law of Directives and Bases (LDB) of 1996 guaranteed differentiated education, to be determined by indigenous communities.

Broadly speaking, there are two main challenges for indigenous peoples in higher education. First is the very low level of access to the system, with small numbers enrolled in any form of higher education. There have been some significant gains: while in 2004 there were estimated to be only 1300 indigenous students in higher education institutions, the figure had risen to around 8000 by 2012 (Lima 2012). Nevertheless, the proportion of all higher education students who are indigenous is only $0.1 \%$, meaning that they are less than a quarter as likely to go to university than the non-indigenous population (David et al. 2013). By 2008, only 21\% of indigenous upper primary schoolteachers had a university degree, a qualification required for teaching at this level (INEP 2009). The second challenge relates to the curriculum: indigenous knowledge and cultural traditions are rarely incorporated within universities, and courses very often are not appropriate for the needs of indigenous communities. This 'curricular ethnocentrism' (David et al. 2013), therefore, presents practical problems for the communities in terms of managing their day-to-day lives, as well as failing to recognize their epistemological and cultural traditions.

There have been a range of responses to the injustices of indigenous higher education from governments, higher education institutions, non-governmental organizations and social movements. It is possible to categorize responses to these challenges in Brazil in three ways:

\section{Affirmative action policies within mainstream institutions}

Public universities in Brazil (starting with the State University of Rio de Janeiro in 2002) have adopted quotas for specific racial/ethnic groups, normally in combination with criteria on socio-economic background (i.e. prior attendance at public rather than private school, and income level) (Childs \& Stromquist 2015; Norões \& Costa 2012). A pioneer in relation to indigenous affirmative action was the State University of Mato Grosso do Sul, which as early as 2003 implemented a quota of $10 \%$ for indigenous students, in addition to a $20 \%$ quota for African descendants (David et al. 2013). The process of mobilization 
across the country culminated with the 2012 federal law which mandates all federal universities to allocate $50 \%$ of their places to students from public schools, and within this proportion, racial quotas corresponding to the demographic proportions in the state in question (Santos, S. 2015). In those states in which there is a significant indigenous population, indigenous people have been able to access federal universities through this scheme.

Some federal universities - for example the University of Western Pará (UFOPA) - have their own targeted quota systems for indigenous students, as do some state universities, while others operate other affirmative action policies such as score bonuses or special entrance exams (vestibulares), e.g. the state universities of Paraná (Cajueiro 2008). Private universities rarely have affirmative action or scholarship schemes, although indigenous students have been able to benefit from the Prouni programme which through which private institutions offer free of charge access for low-income students in exchange for tax breaks. There are also some affirmative action programmes that provide maintenance grants and other support. These actions were spurred on by the project Trilhas de Conhecimento, supported by the Ford Foundation's Pathways to Higher Education initiative (as in Mexico), which ran from 2004-2010. According to Paladino (2012), some 70 universities across the country now have some form of affirmative action programme for indigenous people.

\section{Indigenous courses within mainstream institutions}

There are some examples in public universities of courses designed specifically for indigenous students, with differentiated curricula. Most common amongst these are teacher education courses (licenciaturas), equipping teachers who will be returning to schools in indigenous communities - a need that has increased significantly on account of the expansion of access to primary and secondary schools amongst indigenous children (Grupioni 2003). The first of these were the Insikiran Nucleus of the Federal University of Roraima (UFRR) (Carvalho \& Carvalho 2008), and the State University of Mato Grosso (UNEMAT) in 2001 (Januário \& Silva 2008). Other examples include FAIND (Intercultural Indigenous Faculty), at the Federal University of Grande Dourados, and there are now 26 intercultural teacher education courses across the country (Lima 2012). An important element of these teacher education courses is that the student teachers spend a significant part of the year in their communities, thus helping to ensure that the link with the community is maintained throughout, and that there is less chance of loss of these professionals to urban schools. While the courses are rooted in indigenous culture and knowledge traditions, one of the challenges is that they include students from many different indigenous groups, and therefore multiple cultures and languages. The course at UNEMAT provides plenary sessions in Portuguese, but students utilize their own languages in group work and in creating pedagogical materials (Januário \& Silva 2008). For the most part these courses are restricted to the undergraduate level, although UNEMAT has an especialização course (equivalent of a postgraduate certificate).

These actions started as initiatives emerging from the universities themselves, on the basis of their articulation with indigenous movements and support from committed academic staff. Nevertheless, some government support was provided in the form of the Programme of Higher Education and Indigenous Teacher Education (PROLIND), 
launched in 2005, which emerged from the 2003 Diversity in the University programme (Supported by the Inter-American Development Bank).

\section{Autonomous institutions}

Finally, there are rare examples of dedicated institutions for indigenous people. The Amazonian Centre of Indigenous Education (CAFI)) was founded in Manaus in 2006 to provide courses in project management and ethno-environmental management for selected representatives of indigenous communities around the country. This is a private institution, supported by the Coordination of Indigenous Organizations of Amazonia (COIAB), without any support from public funds and does not have accreditation as a higher education institution (Flores 2008). As is the case with the intercultural teacher education courses, this institution was designed specifically so that students are not permanently removed from their communities, and return to apply what they have learned there. The University of the Forest, in Acre state, is also a form of indigenous institution, and has provided an important opportunity for non-indigenous students to learn from indigenous professors, although has suffered with lack of resources and has now been incorporated into the Federal University of Acre.

Most innovative of these autonomous institutions is perhaps the Institute of Indigenous Knowledge in São Gabriel da Cachoeira, Amazonas state, which is currently being established, but has not yet opened its doors to students (Author 2016; Cammarota et al. 2015; Medeiros \& Lima 2014). It subscribes to a transformative approach to higher education, abandoning traditional disciplines in favour of courses based on indigenous culture and priorities, and involving community elders as well as professors with academic qualifications.

In summary, of these three types of initiative, the first clearly follows the orientation of redistribution, aiming to equalize opportunities to enter mainstream institutions for indigenous people. Here, it is assumed that indigenous people will want to engage with the traditional academic curriculum, and open the door to employment opportunities in mainstream society. The second of these types of initiative acknowledges that the cultural and material context of indigenous communities is distinct, and tailors course content to their specific needs - thus incorporating some elements of the recognition paradigm. The third of these types is clearly following the recognition approach. However, it is important to emphasize that initiatives of the second and third type are few and far between, and the courses are small: CAFI, for example, provides only 30 places a year. For the most part there are extremely low levels of recognition of difference of indigenous communities, and of the need for educational responses in line with their culture and knowledge traditions. Furthermore, much of the emphasis on alterity relates to practical issues such as forming professionals for work in communities, negotiating with government authorities and partnering with NGOs, rather than the more demanding epistemological dimensions. Nevertheless, there are exceptions: the Mato Grosso teacher education course combines the practical elements of alternating between university and community, with an indigenous cosmological element.

The challenge has been interpreted as one of a difficult choice between affirmative action policies that lead to individual empowerment to the detriment of the collective educational rights demanded by indigenous movements, or alternatively differentiated 
courses that are limited to the most part to teacher education, thus limiting the choices of the communities ${ }^{3}$. The government of the Workers' Party (PT) - in power from 2003 until the impeachment of Dilma Roussef in 2016 - did in fact support some differentiated provision of this type, for example the innovative federal universities UNILA $^{4}$ and $\mathrm{UNILAB}^{5}$, focusing on Latin American integration and links with Africa respectively (Author 2016). However, the urban trade union origins of the PT have been associated by some with the relative lack of attention of the government to indigenous issues, and the preference for redistribution over recognition ${ }^{6}$. For the most part, indigenous people in Brazil have been subjected to the tendency across Latin America to convert them into acculturated rural peasants or urban poor (Howard 2009), neither able to live a distinctive lifestyle, nor compete on an equal footing within the mainstream society.

\section{Redistribution and recognition in the two cases}

This final section will consider the theoretical perspectives of redistribution and recognition in relation to the Mexican and Brazilian cases of higher education and the indigenous population. More than classifying these education policies as one or the other, the analysis reflects the challenges and issues that arise from the application of these principles in the complex and ambivalent cases presented. It is plausible that the Mexican case, even with its own problems, presents a more extensive support system than the hesitant efforts from the Brazilian policy framework; in the same way it is also observable that issues around indigenous population, and the magnitude of this population itself, are wider and more recognizable in the case of Mexico. So different policies respond to different social contexts, contrasts that allow us to consider some problematic issues around indigenous higher education. From this analysis we hope to provide a critical insight into theory and political practice. Three problematic issues will be addressed: (i) redistribution responses to recognition claims, (ii) autonomy as a condition for recognition and (iii) equality and the risk of imposing hegemonic discourses.

\section{(i) Redistribution responses to recognition claims}

The analysis shows that initiatives in both countries can to a large extent be understood as affirmative action policies, understood here as politics of redistribution as they pursue the goal of the inclusion of the indigenous youth in the general system. While the Brazilian case bases its support mainly in institutional quotas, in Mexico inclusion is aided through specific backings related with monetary and academic supports in the formal tertiary educational system. One can even consider that, in general, the Mexican intercultural universities offer an inclusive path to the national development model because although the traditional affirmative action model is based on targeted and individual support strategies, these intercultural universities can be understood as an institutional affirmative action where the whole university includes indigenous territories and their people into the general development model of the country (Lehmann, 2015).

\footnotetext{
${ }^{3}$ Douglas Santos, personal communication.

${ }^{4}$ Universidade Federal da Integração Latino-Americana (Federal University for Latin American Integration)

${ }^{5}$ Universidade da Integração Internacional da Lusofonia Afro-Brasileira (University for International Integration of the Afro-Brazilian Lusophony)

${ }^{6}$ Marta Azevedo, personal communication.
} 
Through looking at these strategies as redistribution policies, it is evident that they provide an acknowledgement of the excluded condition of the indigenous population, but it is an exclusion understood as inequality rather than misrecognition. Even though the affirmative action policies deliver a way of inclusion by including indigenous individuals into the regular higher education and national development path, they fail to address the key demand (recognition) and its fundamental problem (misrecognition). This political mismatch risks imposing a political solution which through its discourses, investments and practices hides the main problem. This could deepen its social conflicts - the lack of recognition becomes more problematic - or could erase them - as new generations are included in the general system and official development path, so they end up adapting to them.

\section{(ii) Autonomy as a condition for recognition?}

In contrast, the autonomous universities' experiences presented in each national case could be understood as located under the recognition approach, since they are derived from claims of difference and autonomy. These experiences allow us to explore the problematic relationship between recognition and conditions of autonomy (as explored in Author 2016); for instance, in Mexico, some autonomous universities (e.g. UNISUR Guerrero and UESA-LEIC) are struggling for official recognition, while others (e.g. UNITIERRA) look to operate regardless of recognition by the state - indeed, they reject any possibility of such recognition. In either case - autonomy which looks for or which rejects official recognition - the question is the relevance of the condition of autonomy in a higher education entity in order to consider such initiatives under the recognition framework. There are two questions here: first, is it possible that the state can provide educational alternatives which respect and recognize the autonomy of indigenous communities? And second, can an autonomous institution be recognized if it is not recognized by the state?

In relation to the first issue it can be seen in the two national cases, only the autonomous higher education institutions provide what they are claiming for: to educate from their own indigenous knowledge and categories, promoting their own culture. Even the indigenous teaching programmes in regular universities, despite incorporating elements such as indigenous language, are ultimately adaptations of official curricula to intercultural settings. In logical terms, it is not impossible for an external official body to provide, or at least support, autonomous educational alternatives, for example, through political support, technical advice or economic assistance. This last case may be found in the University of the Forest, which because its financial troubles was incorporated into the federal university of the region. But from the other experiences presented UNITIERRA, Institute of Indigenous Knowledge in São Gabriel da Cachoeira - it seems that actual autonomy is more probable when it comes from the indigenous organizations themselves, initially self-organized and only later officially recognized. In sociological terms, there is a need for agency from indigenous populations in order to obtain structural recognition. First exists the organization self-institutionalized, then the struggle for external recognition.

Autonomous educational institutions, therefore, may seek social or official recognition, in order to, for instance, get governmental funding or any other assistance. This case can be problematic as being officially recognized can bring requirements applied to the general 
system, limiting the original indigenous institutional autonomy. However, there are also autonomous indigenous communities which do not look for external-official recognition, leading to two possible paths of analysis. The first one is just accepting and respecting the autonomous process of each indigenous institution, so this higher education institution responds to its own rules and its own ways of internal recognition. But as a second issue, given that indigenous populations are still part of a wider (national) society, they constitute a matter of public concern for the state and society. From this standpoint, even in the absence of a demand for recognition from indigenous higher education institutions, the state or society are required to provide social or institutional recognition - they cannot ignore the communities and organizations within the polity. This does not necessarily mean official recognition, there can be different ways of symbolic recognition, but in any of its arrangements it equally represents a form of recognition. But, this can also be problematized in terms of sovereignty, as the Western notion of state differs from the one built from indigenous cultures in their claims for autonomy; there can be opposite understandings regarding issues around dominion and power. In the Australian context, for example, Watson (2005, p.43) points out that "Aboriginal sovereignty is different from [western] state sovereignty because it embraces diversity, and inclusivity, rather than exclusivity"; such ontological tensions can make difficult the possibilities of official recognition of the claims for autonomy of indigenous populations.

\section{(iii) Equality and the risk of imposing hegemonic discourses}

This final issue questions if the equality principle applied in the case of higher education, in spite of its search for justice, is ultimately at the service of hegemonic discourses which reinforce the misrecognition of indigenous populations in the countries analysed. As outlined above in relation to questions of 'powerful knowledge', equality of access to mainstream institutions is seen by some as the only way to ensure that marginalized populations are not permanently relegated to a subordinate place in society. However, the equality principle applied in public policies can fall into a problem of imposing a unitary framework - paradoxically - in order to recognize individuals, students, citizens and communities or collectives. Ahenakew (2017) provides an interesting contribution to this matter, by denouncing the fact that institutional efforts for integrating indigenous knowledge in the official educational sphere fail when they instrumentalize this knowledge to maintain the political asymmetry between the white and the aboriginal culture, and when they depoliticize it and minimize conflict through its superficial inclusion.

Two hegemonic discourses or technologies (Ball, 1994) are then visible here: curricular knowledge and the development discourse. An indigenous higher education policy based on affirmative action inside regular universities does not recognize - and therefore neglects - indigenous knowledge, as long as indigenous students are included in a system which educates under the national/regular curriculum framework. Koukannen (2007) argues that the Western university as an institutional result of the dominant 'episteme' is unable to integrate indigenous knowledge because a structural asymmetry will always be present. This knowledge also conforms to a particular development model, so it is not only a cultural imposition, but an economic one too. National economic systems in Latin America, as in other regions of the world, are influenced by free market principles (Gwynne \& Kay, 2000), and the official knowledge imparted by higher education institutions in Brazil and Mexico is influenced by these demands, serving primarily to 
prepare graduates for the labour market. This situation sidelines both the cultural heritage of indigenous population and their conceptions of 'development'.

\section{Conclusion}

This article has presented two national cases of indigenous higher education in Latin America, analysing them through the frameworks of theories of redistribution and recognition, with the aim of understanding the possibilities and trade-offs of different forms of educational intervention for social justice. In both of these countries the limited access to higher education of indigenous people has been addressed through particular initiatives and university models which include integration in regular university through policies of affirmative action in the form of a quota system, in the case of Brazil, and financial and academic support in both of the cases. In the case of Mexico, intercultural universities situated in regions with a high percentage of indigenous population have also been created to foster, as part of their aims, the increased participation of indigenous students. Both of these countries also present cases of autonomous institutions that seek integrate indigenous knowledge systems and demands.

The analysis using the theories of redistribution vs recognition has shown, first that the majority of initiatives in Mexico and Brazil fall under the redistribution approach, since they understand the condition of indigenous people mostly as a marginalized sector of society that needs to be integrated into the national development path through particular actions to give better opportunities of access and completion. Second, the demand of autonomy in relation to recognition has been problematized, since the autonomous options more connected with this approach reflect a tension between the possibilities of addressing cultural particularities, while at the same time being recognized by an educational or governmental system that, as seen in the previous point, exclude them. Linked to this idea, there is the question of whether initiatives to increase the participation of indigenous students have possibilities of opening spaces for recognition, as some of the programmes and systems aim, or if in fact they foster the imposition of hegemonic discourses and therefore reinforce the misrecognition of the indigenous population. It may be that the configuration of higher education systems and programmes based on ideals of equity and redistribution, does in fact block - by integrating and not transforming - cultural, political and social changes of the wider society that would be needed to address these demands.

Furthermore, there are theoretical challenges in relation to the perspectives applied, in terms of asking if those Western paradigms - redistribution and recognition - can actually address the particularities and nuances of such a complex historical issue. This question provokes the consideration of other perspectives which speak from the indigenous populations themselves, avoiding the appropriation of the indigenous voice by Western discourse and theory. 


\section{References}

Ahenakew, C. (2017). Mapping and Complicating Conversations about Indigenous Education. Diaspora, Indigenous, and Minority Education 11 (2): 80-91.

Aikman, S. (1997) Interculturality and intercultural education: A challenge for democracy. International Review of Education, 43(5), 463-479.

Alcántara Santuario, A., \& Navarrete Cazales, Z. (2014). Inclusión, equidad y cohesión social en las políticas de educación superior en México. Revista Mexicana de Investigación Educativa, 19(60), 213-239.

Ames, P. (2012) Language, Culture and Identity in the Transition to Primary School: Challenges to Indigenous Children's Rights to Education in Peru, International Journal of Educational Development, 32(3): 454-464

ANUIES. (2007). Programa de Apoyo a Estudiantes Indígenas en Instituciones de Educación Superior. ANUIES. Retrieved 2 December 2016, from http://paeiies.anuies.mx/public/

Andreotti, V. (2011). Actionable postcolonial theory in education. New York: Palgrave Macmillan.

Badillo Guzmán, J., Casillas Alvarado, M., \& Ortiz Méndez, V. (2008). Políticas de atención a los grupos indígenas en la educación superior mexicana: el caso de la Universidad Veracruzana. Cuadernos Interculturales, 6(10), 33-61.

Ball, S. (1994). Education reform: A critical and post-structural approach: McGraw-Hill Education (UK).

Barrón-Pastor, J. C. (2010). Globalization Perspectives and Cultural Exclusion in Mexican Higher Education. In E. Unterhalter \& V. Carpentier, Global Inequalities and Higher Education: Whose Interests are You Serving? Great Britain: Palgrave MacMillan.

Bertely Busquets, M. (2011). Educación superior intercultural en México. Perfiles Educativos, 33(SPE.), 66-77.

Bourdieu, P. (2011). The forms of capital (1986). Cultural theory: An anthology, 81-93.

Cajueiro, R. (2008) Levantamento de ações afirmativas voltadas aos povos indígenas em universidades públicas federais e estaduais do Brasil. Report produced for the Trilhas de Conhecimento project.

Cammarota, F., Meira, M. A. F. de, Lima, J. H. S. And Chagas, M. (2015) Inovação Nos Modelos De Educação Pública: O Instituto Dos Conhecimentos Indígenas E Pesquisa Do Rio Negro (Iciprn). Paper presented at the CONSAD conference, Brasília, 28-30 May.

Carnoy, M., Santibañez, L., Maldonado-Maldonado, A., \& Ordorika, I. (2002). Barreras de entrada a la educación superior ya oportunidades profesionales para la población indígena mexicana. Revista Latinoamericana de Estudios Educativos, (XXXII), 9-43.

Carvalho, F. and Carvalho, F. A. de (2008) Experiência de formação de professores indígenas do Núcleo Insikiran da Universidade Federal de Roraima. In Mato, D. (ed.) Diversidad Cultural e interculturalidad em educacíon superior. Experiencias em America Latina y el Caribe (IESALC). Caracas: UNESCO-IESALC, pp. 157-166.

Casillas Muñoz, M. de L., \& Santini Villar, L. (2006). Universidad Intercultural: modelo educativo. México D.F.: CGEIB-SEP.

CDI, C. N. para el desarrollo de los P. I. (2016). Fichas de información básica de la población indígena, 2015. México: CDI. Retrieved from http://www.gob.mx/cdi/articulos/fichas-de-informacion-basica-de-la-poblacionindigena-2015?idiom $=\mathrm{es}$ 
Childs, P., and N. Stromquist. 2014. Academic and Diversity Consequences of Affirmative Action in Brazil. Compare, 45 (5), 792-813.

Clegg, S. (2011) Cultural capital and agency: connecting critique and curriculum in higher Education, British Journal of Sociology of Education, 32(1), 93 - 108.

CNBS-SEP. (2016). SEP | SES | Coordinación Nacional de Becas de Educación Superior. Retrieved 2 December 2016, from http://www.cnbes.sep.gob.mx/

Coulthard, G. (2014). Red Skin, White Masks: Rejecting the Colonial Politics of Recognition. Minneapolis: University of Minnesota Press.

Cueto, S., G. Guerrero, J. León, E. Seguin and I. Muñoz (2009)'Explaining and Overcoming Marginalisation in Education: A Focus on Ethnic/Language Minorities in Peru', Background paper for the EFA Global Monitoring Report 2010, Paris: UNESCO

Cueto, S., J. Escobal, M. Penny and P. Ames (2011) Tracking Disparities: Who Gets Left Behind? Initial Findings from Peru, Young Lives Round 3 Survey Report, Oxford: Young Lives

David, M., Melo, M. L. and Malheiro, J. M. da S. (2013) Desafios do currículo multicultural na educação superior para indígenas. Educação e Pesquisa, 39 (1), 111-125.

Didou Aupetit, S., \& Remedi, E. (2006). Pathways to Higher Education: una oportunidad de educación superior para jóvenes indígenas en México. México: Anuies.

Didou-Aupetit, S. (2013). Cooperación internacional y educación superior indígena en América Latina: constitución de un campo de acción. Revista Iberoamericana de Educación Superior, 4(11), 83-99.

DOF, D. Of. de la F. (2008) Catálogo de las Lenguas Indígenas Nacionales: Variantes Lingüísticas de México con sus autodenominaciones y referencias geoestadísticas. Retrieved from http://www.inali.gob.mx/pdf/CLIN_completo.pdf

Flores, L. (2008) Formação Indígena na Amazônia Brasileira. In Mato, D. (ed.) Diversidad Cultural e interculturalidad em educacíon superior. Experiencias em America Latina y el Caribe (IESALC). Caracas: UNESCO-IESALC, pp. 139-146.

Flores-Crespo, P. and Barrón Pastor, J. (2006). El programa de apoyo a estudiantes indígenas: ¿nivelador académico o impulsor de la interculturalidad? México D.F.: Anuies.

Fraser, N. (1995). Recognition or redistribution? A critical reading of Iris Young's Justice and the Politics of Difference. Journal of Political Philosophy, 3(2), 166-180.

Fraser, N. (1998). From Redistribution to Recognition? Dilemmas of Justice in a 'PostSocialist' Age. In Feminism and politics, edited by A. Philipps. New York: Oxford University Press.

Fraser, N., \& Honneth, A. (2003). Redistribution or recognition?: a political-philosophical exchange. London: Verso.

Friedman, J. (1994). The politics of communitarianism. Critical Review, 8(2), 297-340.

Grupioni, L. D. B. (2003) Experiências e Desafios na Formação de Professores Indígenas no Brasil. Em Aberto, 20 (76), p. 13-18.

Gwynne, R. N., \& Kay, C. (2000). Views from the periphery: futures of neoliberalism in Latin America. Third World Quarterly, 21(1), 141-156.

Honneth, A. (1992). Integrity and disrespect: Principles of a conception of morality based on the theory of recognition. Political theory, 20(2), 187-201.

Honneth, A. (2004). Recognition and justice outline of a plural theory of justice. Acta Sociologica, 47(4), 351-364.

Hornberger, Nancy H. (1988). Bilingual education and language maintenance. A southern Peruvian Quechua case. Dordrecht: Foris Publication. 
Howard, R. (2009) Education reform, indigenous politics, and decolonisation in the Bolivia of Evo Morales. International Journal of Educational Development, 29 (6), 583-593.

IBGE (2012). Os indígenas no Censo Demográfico 2010: primeiras considerações com base no quesito cor ou raça. Available at: http://www.ibge.gov.br/indigenas/indigena censo2010.pdf. Accessed $18 / 12 / 2016$

INEP (2009) Um olhar sobre a educação indígena com base no Censo Escolar de 2008. Disponível em: http://www.consed.org.br/media/download/54b662f7025ff.pdf Accessed 18/12/2016

Januário, E. and Silva, F. S. (2008) Estudo sobre a experiência dos Cursos de Licenciatura para a Formação de Professores Indígenas da Universidade do Estado de Mato Grosso. In Mato, D. (ed.) Diversidad Cultural e interculturalidad em educacíon superior. Experiencias em America Latina y el Caribe (IESALC). Caracas: UNESCOIESALC, pp. 147-156.

Khoo, S., \& Walsh, A. (2016). Regenerating education from below: endogenous tertiary education in alternative development niches. Policy \& Practice: A Development Education Review, (22), 10-34.

Kuokkanen, R. 2007. Reshaping the University: Responsibility, Indigenous Epistemes, and the Logic of the Gift. Vancouver: UBC Press.

Lehmann, D. (2015). Convergencias y divergencias en la educación superior intercultural en México. Revista Mexicana de Ciencias Políticas Y Sociales, 60(223), 133-170.

Lima, A. C. de S. (2012) A Educação Superior de Indígenas no Brasil contemporâneo: reflexões sobre as ações do Projeto Trilhas de Conhecimentos. Revista História Hoje, 1 (2), p. 169-193

Lopes Cardozo, M.T.A. (2012). Transforming pre-service teacher education in Bolivia: from indigenous denial to decolonisation? Compare, 42(5), 751-772.

Martínez Casas, R. (2011). La formación de los profesionistas bilingües indígenas en el México contemporáneo. Perfiles Educativos, 33(SPE.), 250-261.

Mateos Cortés, L. S., \& Dietz, G. (2011). Interculturalidad y educación intercultural en México: Un análisis de los discursos nacionales e internacionales en su impacto en los modelos educativos mexicanos. CGEIB-SEP.

Mateos Cortés, L. S., \& Dietz, G. (2016). Universidades interculturales en México: balance crítico de la primera década. Revista Mexicana de Investigación Educativa, 21(70), 683-690.

May, Stephen (Ed.). (1999). Indigenous Community-Based Education. Clevedon, UK: Multilingual Matters.

McCowan, T. (2016a) Three Dimensions of Equity of Access to Higher Education." Compare, 46 (4): 645-665.

McCowan, T. (2016b) Forging Radical Alternatives in Higher Education: The Case of Brazil. Other Education, 5 (2): 196-220.

Medeiros, I. A. and Lima, J. H. S. (2014) Diálogo de saberes no Instituto dos Conhecimentos Indígenas e Pesquisa do Rio Negro (AM). Parcerias Estratégicas, 19 (39), 35-48.

Norões, K., and Costa, B. (2012) Affirmative Policies in Brazil: Black Movements and Public Higher Education. Educational Thought, 9 (1): 24-31.

Paladino, M. (2012) Algumas notas para a discussão sobre a situação de acesso e permanência dos povos indígenas na educação superior. Práxis Educativa, 7, 175195. 
Pedrosa, R., Simões, T., Carneiro, A., Andrade, C., Sampaio, H. and Knobel, M. (2014) Access to higher education in Brazil. Widening Participation and Lifelong Learning, 16 (1), 5- 33.

Rojas-Cortés, A., \& González-Apodaca, E. (2016). El carácter interactoral en la educación superior con enfoque intercultural en México. LiminaR, 14(1), 73-91.

Santos, B. de S. (2015). Epistemologies of the South: justice against epistemicide. New York: Routledge.

Santos, S. A. dos (2015) Between left and right: Are descendants of slaves in Brazil still Black? Cultural Dynamics, 1-18.

Schmelkes, S. (2008). Creación y desarrollo inicial de las universidades interculturales en México: problemas, oportunidades, retos. In D. Mato, Diversidad cultural $e$ interculturalidad en educación superior: experiencias en América Latina. Bogotá: UNESCO-IESALC.

Schmelkes, S. (2009). Intercultural universities in Mexico: progress and difficulties. Intercultural Education, 20(1), 5-17.

Schmelkes, S. (2013). Indigenous students as graduates of Higher Education Institutions in Mexico. In R. Cortina (Ed.) The Education of Indigenous Citizens in Latin America (Vol. 95, p. 124). Great Britain: Multilingual Matters.

SEP, C. G. de E. I. B. (2004). Marcos formales para el trabajo educativo intercultural bilingüe. México D.F.: CGEIB-SEP.

Skutnabb-Kangas, T. , Phillipson, R. , Mohanty, A. K. , and Panda, M. (eds) (2009) Social Justice through Multilingual Education. Bristol: Multilingual Matters .

Spring, J. (2000). The Universal Right to Education: Justification, Definition, and Guidelines New Jersey: Lawrence Erlbaum.

Tapia Guerrero, L. A. (2016). El subsistema de universidades interculturales en México. Entre la política social y la política educativa. Revista Latinoamericana de Estudios Educativos, 46(1), 7-50.

Taylor, C. (1994). Multiculturalism: Examining the politics of recognition: Princeton, NJ: Princeton University Press.

Touraine, A. (2002). The importance of social movements. Social Movement Studies, 1(1), 89-95.

UNAM. (2014). Sistema de becas para estudiantes indígenas. Retrieved 2 December 2016, from

http://nacionmulticultural.unam.mx/portal/educacion_docencia/sistema_becasC. html

UNICEF/INEE. (2016). Panorama Educativo de la Educación Indígena 2015. México D.F.: Instituto Nacional para la Evaluación de la Educación / Fondo de las Naciones Unidas para la Infancia (UNICEF).

UNITIERRA. (n.d.). Bienvenido a Unitierra. Retrieved 2 December 2016, from http://unitierraoaxaca.org/

Wheelahan, L. (2007) How competency-based training locks the working class out of powerful knowledge: A modified Bernsteinian analysis. British Journal of Sociology of Education 28, (5): 637-51.

Young, M. F. D. (2008) Bringing Knowledge Back In: From social constructivism to social realism in the sociology of education. London: Routledge. 